\title{
Shark-cetacean trophic interactions during the late Pliocene in the Central Eastern Pacific (Panama)
}

\author{
Dirley Cortés, Carlos De Gracia, Jorge D. Carrillo-Briceño, \\ Gabriel Aguirre-Fernández, Carlos Jaramillo, \\ Aldo Benites-Palomino, and Joaquín Enrique Atencio-Araúz
}

\begin{abstract}
We provide a description of the remains of a fossil whale from western Panama. The record consists of appendicular remains of a mysticete, which has been assigned to Balaenopteridae. These remains, found in the sediments of the late Pliocene Burica Formation, represent the first record of a marine mammal in the Neogene sedimentary succession of the Burica Peninsula. Two different types of shark bite marks, serrated and deep-unserrated, found on the radius and phalanges suggest scavenging by at least two white shark (Carcharodon) individuals. The deep, unserrated marks were possibly caused by continual biting by sharks. Both the morphology of the shark bite marks and their relative location on the whale limb bones constitute evidence of sharkcetacean trophic interaction. Although the specimen lacks diagnostic features that would allow a species-level identification, it does provide new information on the vertebrate fauna of a very poorly prospected Central Eastern Pacific exposure, thus opening an opportunity for exploring the marine fauna during a critical episode in Earth history, the Plio-Pleistocene transition.
\end{abstract}

Dirley Cortés. Redpath Museum, McGill University, 859 Sherbrooke St. W., Montreal QC H3A 0C4, Canada. Smithsonian Tropical Research Institute, Balboa-Ancón 0843-03092, Panamá, Panamá. dirley.cortes@mail.mcgill.ca Carlos De Gracia. Smithsonian Tropical Research Institute, Balboa-Ancón 0843-03092, Panamá, Panamá.degraciac@gmail.com Jorge D. Carrillo-Briceño. Paläontologisches Institut und Museum, Karl-Schmid-Strasse 4, 8006 Zurich, Switzerland. Smithsonian Tropical Research Institute, Balboa-Ancón 0843-03092, Panamá, Panamá. jorge.carrillo@pim.uzh.ch Gabriel Aguirre-Fernández. Paläontologisches Institut und Museum, Karl-Schmid-Strasse 4, 8006 Zurich, Switzerland. gabriel.aguirre@pim.uzh.ch

Cortés, Dirley, De Gracia, Carlos, Carrillo-Briceño, Jorge D., Aguirre-Fernández, Gabriel, Jaramillo, Carlos, Benites-Palomino, Aldo, and Atencio-Araúz, Joaquín Enrique. 2019. Shark-cetacean trophic interactions during the late Pliocene in the Central Eastern Pacific (Panama). Palaeontologia Electronica 22.2.49A 1-13. https://doi.org/10.26879/953 palaeo-electronica.org/content/2019/2652-pliocene-whale-from-panama 
Carlos Jaramillo. Smithsonian Tropical Research Institute, Balboa-Ancón 0843-03092, Panamá, Panamá. ISEM, U. Montpellier, CNRS, EPHE, IRD, Montpellier, France. JaramilloC@si.edu

Aldo Benites-Palomino. Smithsonian Tropical Research Institute, Balboa-Ancón 0843-03092, Panamá, Panamá. Departamento de Paleontología de Vertebrados, Museo de Historia Natural, Universidad Nacional Mayor de San Marcos; Avenida Arenales 1256, Lima 14, Perú. aldomar1955@gmail.com Joaquín Enrique Atencio-Araúz. Colegio Punta Burica, Chiriquí Province, Panamá. juniormurcie@latinmail.com

Keywords: Mysticeti; shark bite marks; Neogene; late Pliocene; Central America; trophic interaction

\section{INTRODUCTION}

Baleen whales (Mysticeti) are a diverse group of filter-feeding cetaceans that includes the largest extant marine mammals (e.g., Tsai and Kohno, 2016; Marx and Kohno, 2016; Slater et al., 2017; Fordyce and Marx, 2018). As already highlighted elsewhere (Aguirre-Fernández et al., 2017), except for the Pisco Formation in Peru (e.g., Bianucci et al., 2016a, 2016b; Di Celma et al., 2017), the fossil record of cetaceans from the Neotropics is poorly studied compared to that from higher latitudes. Balaenopterid mysticetes have been reported in Neogene and Quaternary sequences worldwide from the early late Miocene to the late Pleistocene (Bisconti, 2010). The earliest fossil balaenopterid comes from the early late Miocene $(\sim 7-10 \mathrm{Ma})$ of the North Pacific Ocean (Deméré et al., 2005). Pliocene balaenopterid records include several occurrences from the early Pliocene (Zanclean) of Antwerp, Belgium (van Beneden, 1882) and the late Pliocene (Piacenzian) of California, USA (Deméré, 1986), Italy (Deméré et al., 2005), northern Chile (Dathe, 1983; Bisconti, 2010), and southern Nicaragua (Lucas et al., 2009). Although some Pliocene remains have been reported for the Pisco Formation of northwestern Peru (e.g., de Muizon and DeVries, 1985; DeVries, 1988), the Pliocene strata of the Pisco Formation are now generally regarded as late Miocene, e.g., Ehret et al. (2012). Pleistocene records have been reported mainly from Peru (Martínez and Jacay, 2000), Ecuador (Bianucci et al., 2006), and North America (Miller, 1971; Barnes and Mitchell, 1975; Tsai and Boessenecker, 2017), including the Champlain Sea, Canada (Harington, 1977), Florida (Morgan, 1994), California (Barnes and Mitchell, 1975), and Georgia, USA (Noakes et al., 2013).

Shark-cetacean trophic interactions have been widely reported from the fossil record (e.g., Deméré and Cerutti, 1982; Bianucci et al., 2000, 2010; Ehret et al., 2009; Godfrey et al., 2018, and references therein) including traces deriving both from active predation and scavenging (e.g., Ehret et al., 2009; Govender and Chinsamy, 2013; Collareta et al., 2017; Bianucci et al., 2018; Godfrey et al., 2018). For instance, Aguilera et al. (2008) described a cetacean lumbar vertebra pierced by a tooth of Carcharocles megalodon from the Miocene of Venezuela (Carrillo-Briceño et al., 2016), and Ehret et al. (2009) described a scavenging event by a Carcharodon sp. on a mysticete whale from the Pliocene of the Pisco Formation in Peru. Postmortem tooth marks by sharks on cetacean bones have been reported from the early Pliocene western coast of South Africa where Carcharodon sp. was identified as a potential predator (Govender and Chinsamy, 2013; Govender, 2015). Likewise, shark tooth marks found on both the ulna and the radius of a balaenopterid cetacean from the Miocene of Argentina were indicative of scavenging or predation (Noriega et al., 2007).

Herein, we report the first record of a balaenopterid mysticete from the late Pliocene (Piacenzian-Zanclean) sediments of the Charco Azul Group in the Burica Peninsula, western Panama, and discuss the ecological implications of several shark bite marks found on the specimen.

\section{STUDY AREA AND GEOLOGICAL SETTING}

The Burica Peninsula straddles the border between Panama and Costa Rica along the Tropical Eastern Pacific (Figure 1.1). This region was uplifted recently following the subduction of the Cocos ridge underneath the Panama microplate (Baumgartner et al., 1989; Mora et al., 1989; Corrigan et al., 1990). The collision, which began in the late Pleistocene (uplift rates of 1-8 $\mathrm{m} \mathrm{ka}^{-1}$ ) (LeonRodriguez, 2007) and continues today (2-3 m $\mathrm{ka}^{-1}$ ) (Davidson, 2010), produced a rapid uplift, elevating the Talamanca Range to $4000 \mathrm{~m}$ (Coates and Obando, 1996; Coates, 1997). That allowed 

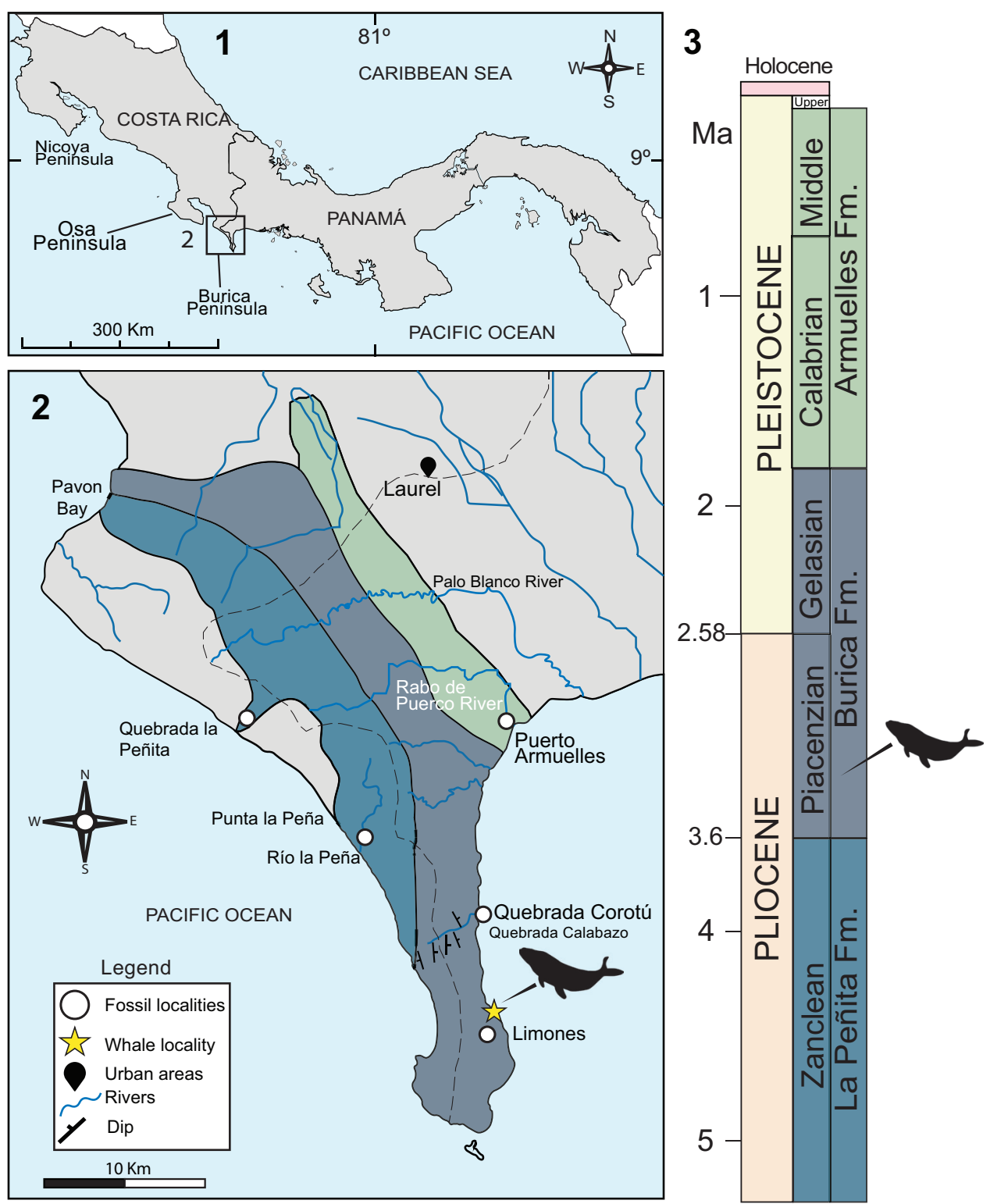

FIGURE 1. Geological setting of the find. 1, Map of Central America, showing the Burica Peninsula. 2, Geological map of the Burica Peninsula, indicating the fossil locality. 3, Schematic chronostratigraphic section, showing the approximate position of the whale remains. Map modified from Coates et al. (1992); ages from Corrigan et al. (1990) and Schwarzhans and Aguilera (2013). Ma: million years; Fm., Formation.

the Charco Azul Group to become exposed subaerially in the Burica Peninsula (Figure 1.2) (Corrigan et al., 1990; O'Dea et al., 2012). The Charco Azul Group is a $4500 \mathrm{~m}$ thick succession of marine sediments (Olsson, 1942; Coates et al., 1992; O'Dea et al., 2007) comprising the Peñita, Burica, and Armuelles Formations (Leon-Rodriguez, 2007; De Gracia et al., 2012) (Figure 1.3).

The fossil material described herein was found in a coastal outcrop near Quebrada Calabazo creek in Playa Limones (geographic coordi- nates: $8^{\circ} 08^{\prime} 53.6^{\prime \prime} \mathrm{N}, 8^{\circ} 52^{\prime} 27.4^{\prime \prime} \mathrm{W}$ ) (Figure 1.2). The strata containing the fossil belong to the Burica Formation, which is $2800 \mathrm{~m}$ thick and dominated by volcaniclastic turbidites. Dated as late Pliocene to middle Pleistocene (Corrigan et al., 1990; Coates et al., 1992; Leon-Rodriguez, 2007) (Figure 1.3), the Burica Formation is divided into two members (Coates et al., 1992; O'Dea et al., 2012; De Gracia, 2015). The balaenopterid specimen (Figure 2) was found in the late Pliocene lower member, which was deposited at water depths around 
$2000 \mathrm{~m}$ and consists of coarse-grained proximal turbidites (Corrigan et al., 1990; Collins et al., 1995; Leon-Rodriguez, 2007; O'Dea et al., 2007). Based on the stratigraphic column of Leon-Rodriguez (2007) and the geographic location of the site, the approximate stratigraphic position of the fossil is in the lower part of the lower member of the Burica Formation ( $700 \mathrm{~m}$ above the base of the $2800 \mathrm{~m}$ thick formation).

The specimen was collected in a poorly consolidated, fine-grained green glauconitic siltstone with abundant mollusks, echinoids, and crustacean remains.

\section{METHODS AND REPOSITORIES}

The balaenopterid remains are represented by a partial right forelimb belonging to a single individual, consisting of the ulna, radius, five carpals, two metacarpals, three phalanges, and one indeterminate bone fragment (Figures 2-3). This specimen was recovered in 2016 under low-tide conditions by Joaquín Atencio and members of the local community (Félix Orocú and Joel Orocú). An isolated white shark tooth (Carcharodon carcharias, Figure 3.5) was found near the cetacean remains. The specimens are housed in the Universidad de Panamá, Panama, in two different collections. The balaenopterid specimen is housed in the Colección Nacional de Referencia de Mastozoología del Museo de Vertebrados, under collection number MNUP-1795. The white shark tooth ( $C$. charcarias) is housed in the Museo de Biología Marina y Limnología, under collection number MBML-CF01. We followed the terminology of Deméré et al. (2005), Cicimurri and Knight (2009), Ehret et al. (2009), Bianucci et al. (2010), Bisconti (2010), and Marx et al. (2016) to describe the balaenopterid bones and the shark bite marks.

\section{SYSTEMATIC PALEONTOLOGY}

\author{
Order CETACEA Brisson, 1762 \\ Suborder MYSTICETI Flower, 1864 \\ Family BALAENOPTERIDAE Gray, 1864 \\ Balaenopteridae gen. et $\mathrm{sp}$. indet. \\ Figures 2-3, Table 1
}

\section{Referred Material}

MNUP-1795 consists of a partial right forelimb measuring $184 \mathrm{~cm}$ in length. A very incomplete fragment found near the radius cannot be identified but may be what remains of the humerus. The ulna and radius were not articulated in their anatomical position. Part of the carpals are also preserved, including five oval-shaped bones. Only two metacarpals and three phalanges are preserved, the latter being strongly eroded. The bones are highly porous on their surfaces, and several shark bites are recognizable on some of them (Figure 3).

\section{Age and Type Locality}

Sediments collected by Corrigan et al. (1990), where the whale was found, have been dated as late Pliocene by planktic foraminifera zones N18/ $\mathrm{N} 19$, by the presence of Globorotalia margaritae Bolli and Bermúdez, 1965, and contain the calcareous nannofossil Reticulofenestra pseudoumbilica Gartner, 1969, Zanclean-Piacenzian in age. Dating follows the Neogene biostratigraphy provided in Hilgen et al. 2012 (figure 29.8 and 29.10).

\section{Taphonomy}

The specimen was found in the tidal zone of the Limones beach and was partially exposed by wave erosion; no other cranial or postcranial elements have been found yet. All elements have a light brown color, and on the radius and two phalanges, clear shark bite marks are recognizable. The presence of this isolated and partially preserved forelimb suggests that the carcass was consumed by scavengers, including sharks. Scavengers could have disarticulated the forelimb from the skeleton; it would then have sunk and been buried by sediments. Before the elements were buried, however, they remained exposed on the seafloor, as indicated by the presence of bryozoans and serpulids covering the exposed areas and bite marks (Figure 3.1-4).

\section{Description}

Ulna. The ulna is elongated but shorter than the radius. The proximal end of the ulna is broken. The posterior margin is more concave than the anterior. The olecranon process is present, but broken in dorsal view. The dorsal surface of the ulna is more convex than the ventral one. The ulna is as wide in the mid part of the diaphysis as it is at the proximal epiphysis. The proximal epiphysis of the ulna is circular in cross section, whereas the distal epiphysis is very oval in shape (flattened and wider than the proximal end). There is a process on the anterodistal margin of the ulna. A small anterior process begins on the proximal metaphysis of the ulna. On the distal end, a deep and very rough surface forms the articulation facet for the carpal (Figure 2.2).

Radius. The radius is elongated, with a straight anterior border and a slightly concave posterior 


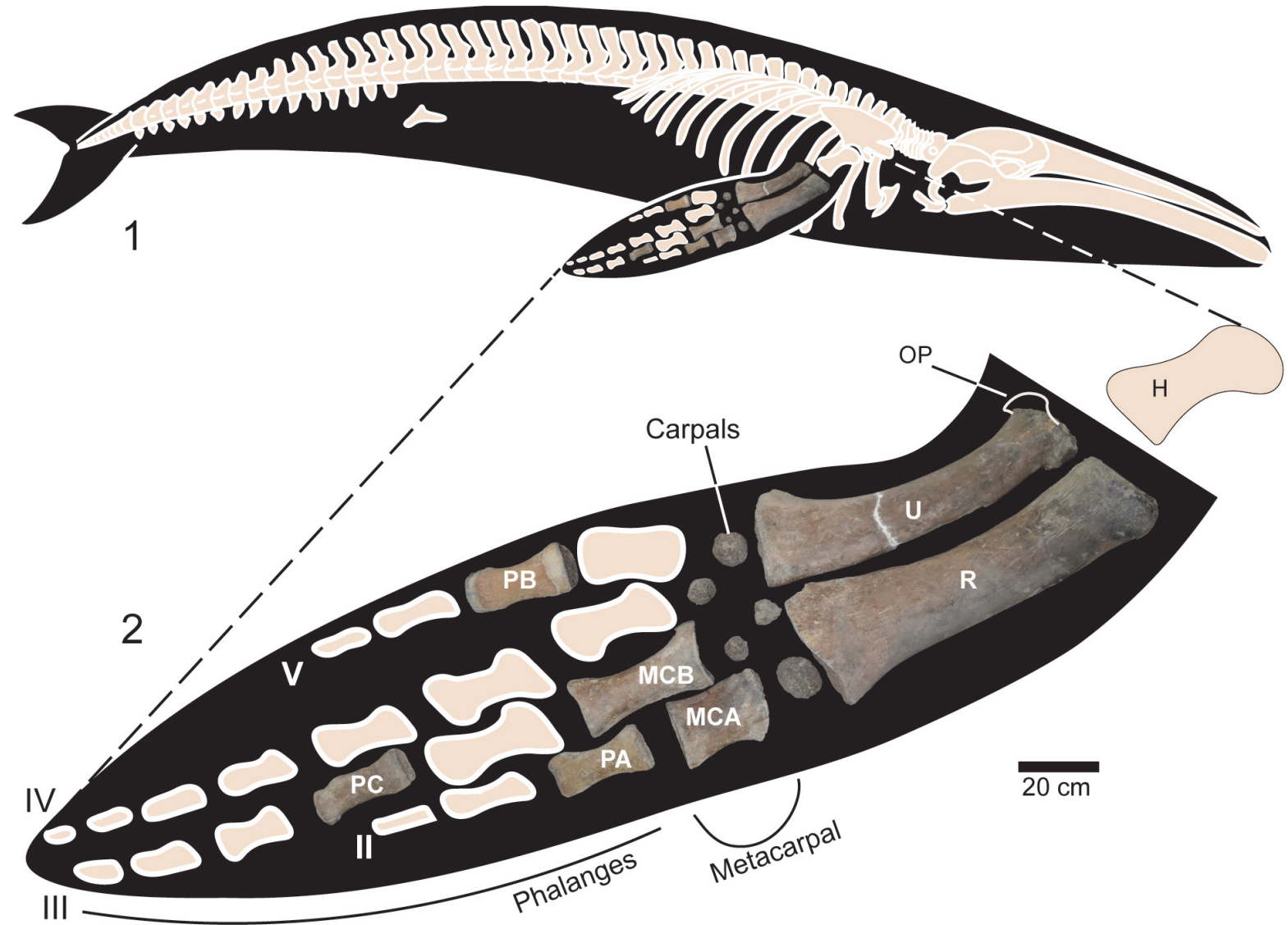

FIGURE 2. 1, Right lateral view of the skeleton of a generalized mysticete whale (modified from Marx and Fordyce, 2015; Marx et al., 2016). 2, Dorsal view of the reconstructed forelimb of specimen MNUP-1795 from the late Pliocene of Panama. Abbreviations: $\mathrm{H}$, humerus; MCA, metacarpal A; MCB, metacarpal B; OP, olecranon process; PA, phalanx $A$; $P B$, phalanx $B$; $P C$, phalanx $C ; R$, radius; $U$, ulna. Roman numerals indicate the digits of the right forelimb.

border. The distal end is wider than the proximal one (Table 1). The proximal facet for the carpals is very straight. Because the distal end is broken, the features of the distal facets cannot be assessed. In distal view, the epiphysis of the radius is less oval than that of the ulna. The proximal end of the radius is significantly more robust than the proximal end of the ulna. The posterodorsal surface of the radius displays several shark bites traces. The dorsal surface of the radius is more convex than the dorsal surface of the ulna (Figure 2.2).

Carpals. Five elements are identified as carpal bones based on their oval shape. The diameter of the carpals varies between 6 and $9 \mathrm{~cm}$ (Figure 2.2).

Metacarpals. Because of the highly disarticulated condition of the bones, the natural position of the metacarpals cannot be assessed with confidence. However, given the small size and the anterior curvature along the shaft of metacarpal A (Figure 2.2), it might be metacarpal 2 or metacarpal 5 . The proximal facets of the metacarpals are very deep. Metacarpal $B$ is eroded on the distal end but some features can be identified: metacarpal $B$ is longer but thinner than metacarpal A (Figure 2.2); the proximal facet for articulation with the corresponding carpal is very deep and rough; a flat process is present on the proximal dorsal border of metacarpal $\mathrm{B}$; the posterior margin of metacarpal $\mathrm{B}$ is as curved as the anterior one and has a cleavage along its shaft.

Phalanges. Three bony elements were identified as phalanges (Figure 2.2). Phalanx $A$ is flat and long with a large process on the distal anterior ramus. Phalanx $B$ is the most massive. Phalanx $C$ is equally curved on its anterior and posterior margins. The position of the phalanges in the diagram was based on the relative sizes of the preserved elements. However, neither natural position nor distance between elements can be assigned with 


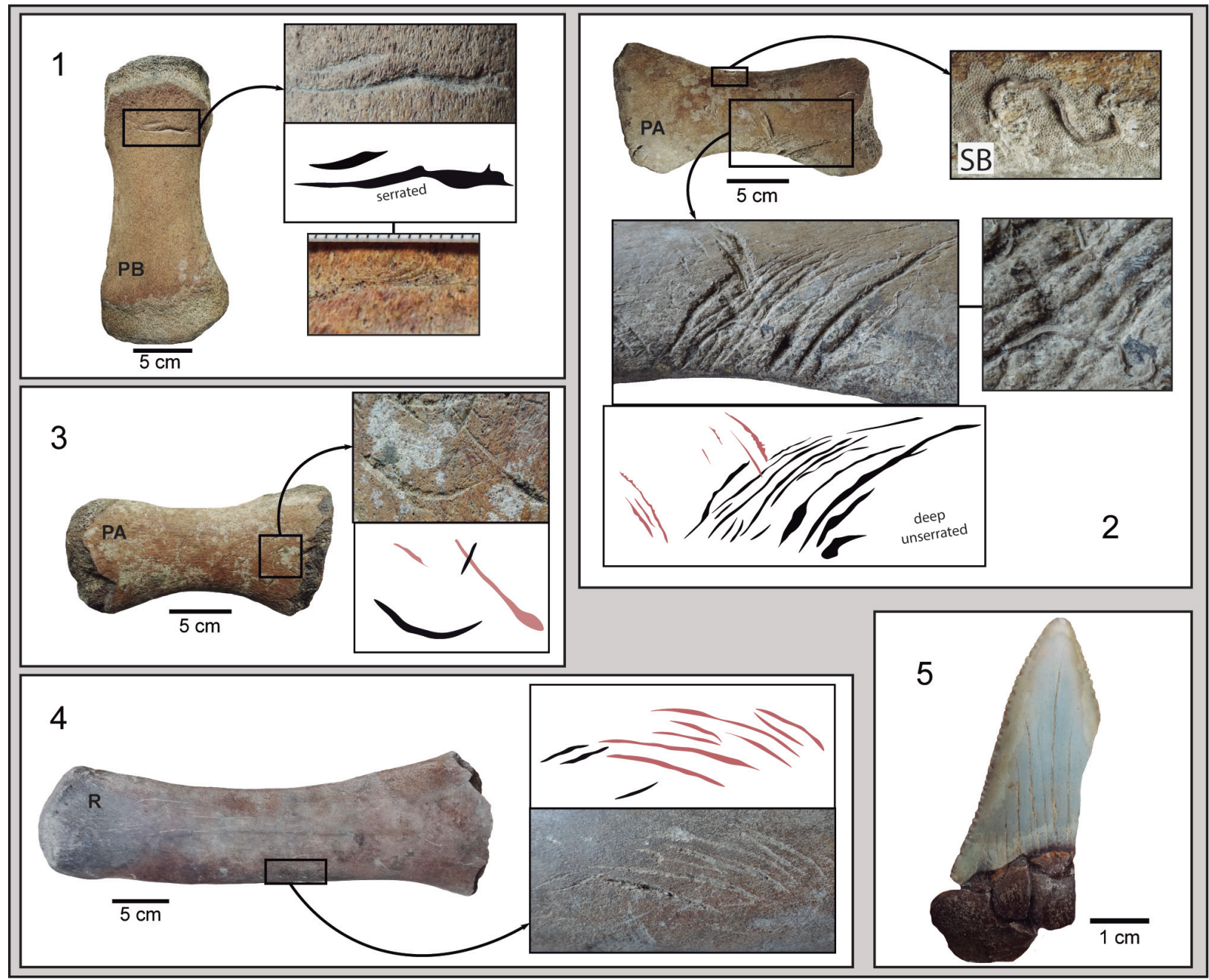

FIGURE 3. Balaenopterid and shark remains from the late Pliocene of Panama. 1-4, Bones affected by shark bite marks, with close-up photographs and line drawings of the incisions (1-3: phalanges; 4: radius). SB = Serpulids and bryozoans covering the surface of the fossil bones and partly draping the underlying bite marks. 5, Carcharodon carcharias tooth (MBML-CF01) found near the cetacean remains. Abbreviations: PA, phalanx A; PB, phalanx B; R, radius. Colors on bite marks line drawings indicate the differentiation of the bite damages by two potential and different-sized conspecific shark individuals.

confidence because the bones lack diagnostic features and clues about articulation.

\section{Remarks}

The specimen MNUP-1795 is identified as belonging to Balaenopteridae based on a number of characters of the forelimb bones, including a radius and ulna remarkably elongated and flattened (Bisconti, 2010) and hourglass shaped; proximal epiphyses on both ulna and radius; and lack of metacarpal I and digit I (following the proposed interpretation of the original position of the bones).

Shark bite marks are recognizable on the radius and on two of the phalanges, i.e., phalanx $A$ and phalanx $B$ (Figure 3.1-4). There are two types of bite marks preserved, unserrated, and serrated. Unserrated marks are found on both phalanx $A$ and the radius (Figure 3.2-4). Phalanx A reveals 26 bite marks on both its medial and lateral faces, the longest being $70 \mathrm{~mm}$ long; the marks are deep ( $\sim-5$ $\mathrm{mm}$ ) and wide $(\sim 2-4 \mathrm{~mm})$ with parallel and crosshatched patterns, mostly clustered at the margin of the bone (Figure 3.2). Besides these, eight shallow marks can be discerned in the anterior margin of the diaphysis almost at the midpoint of the radius (Figure 3.4). The marks are oriented roughly parallel to each other, the longest being $140 \mathrm{~mm}$ long.

A second type of bite mark is present on the distal section of phalanx B (Figure 3.1). In phalanx $B$, two short but deep marks are seen running par- 
TABLE 1. Measurements of the balaenopterid fin elements, specimen MNUP-1795, lower Burica Formation, Panama.

\begin{tabular}{lc}
\hline \multicolumn{1}{c}{ Measurements } & cm \\
\hline Maximum length of the radius & 84 \\
Maximum width of the radius & 23 \\
Anteroposterior width of the proximal end of the & 23 \\
radius & \\
Anteroposterior width of the distal end of the radius & 33 \\
Dorsoventral height of the proximal end of the radius & 19 \\
Dorsoventral height of the distal end of the radius & 15 \\
Length of the ulna & 79 \\
Maximum width of the ulna & 31 \\
Anteroposterior width of the proximal end of the ulna & 20 \\
Anteroposterior width of the distal end of the ulna & 28 \\
Dorsoventral width of the proximal end of the ulna & 14 \\
Dorsoventral width of the distal end of the ulna & 9 \\
Minimum diameter of metacarpal A & 9 \\
Minimum width of metacarpal A & 15 \\
Minimum diameter of metacarpal B & 6 \\
Minimum width of metacarpal B & 11 \\
Length of metacarpal A & 29 \\
Length of metacarpal B & 23 \\
Length of phalanx A & 24 \\
Length of phalanx B & 24 \\
Length of phalanx C & 22 \\
\hline & \\
\hline
\end{tabular}

allel to each other; the longer of these two marks is $50 \mathrm{~mm}$ long, and it shows several millimeter-long serrations.

\section{DISCUSSION}

The fossil record of the Burica Formation includes foraminifera, mollusks, crustaceans, fish otoliths, and shark teeth (Olsson, 1942; Corrigan et al., 1990; Collins et al., 1995; De Gracia et al., 2012; De Gracia, 2015; Carrillo-Briceño et al., 2018, table S6). The record presented here represents the first occurrence of mammal remains from this succession.

Prior to this work, the only record of a mysticete for the Neogene of Central America consisted of 14 vertebral centra, one humerus, and 10 incomplete ribs from a single individual from the $\mathrm{EI}$ Santo Formation (Pliocene) in southern Nicaragua (Lucas et al., 2009). Here we add a second record. Although the size of a whale's skull can provide a good estimate of body size (Pyenson and Sponberg, 2011; Lambert et al., 2010), forelimb mea- surements, in contrast, are unreliable measures of body size. For example, the fin of a humpback whale $(\sim 89 \mathrm{~cm})$ is somewhat longer than that of a blue whale $(\sim 81 \mathrm{~cm})$, but its body length is considerably shorter than a blue whale's ( 16 m vs. $27 \mathrm{~m}$ ) (Johnson and Wolman, 1984; Aguilar, 2009). Thus, we cannot estimate the body size of our specimen.

The shark bite marks indicate either active predation or scavenging. Neogene cetacean remains have been found with the bite marks of top predator sharks such as Carcharocles spp. and Carcharodon (e.g., Bianucci et al., 2000; Aguilera et al., 2008; Ehret et al., 2009; Bianucci et al., 2010; Godfrey et al., 2018, and references therein). Shark predation on mysticete whales is rarely reported, but it may occur more often than previously thought. Dicken et al. (2015) reported the first direct observation of dusky sharks (Carcharhinus obscurus) attacking a humpback whale calf during the annual sardine run off South Africa.

However, sharks often scavenge large mysticete whales while hunting smaller odontocetes (Govender and Chinsamy, 2013; Govender, 2015), and the balaenopterid whale from the Burica Formation of Panama was probably not killed by active predation. Cetacean carcasses are an energy-rich food source for sharks (Long and Jones, 1996; Bornatowski et al., 2012; Anderson and Bell, 2014). Carcharodon carcharias is known to feed on a floating carcass over several days, with observations of scavenging by lone individuals (Fallows et al., 2013; Dicken et al., 2015) or by two individuals simultaneously (Curtis et al., 2006). Considering the similarity of the two types (serrated and unserrated) of shark-bite marks preserved, it is possible that they were made by two different-sized conspecific shark individuals (e.g., C. carcharias), who scavenged on the same mysticete carcass. Serrated traces with a similar morphology, produced by Carcharodon carcharias, have been described on dolphin remains from both the Pliocene and the Holocene (Cigala-Fulgosi, 1990; Schouten, 2017), suggesting that marks in MNUP-1795 are those of a white shark (C. carcharias). A similar incident of scavenging on a balaenopterid-whale skeleton from the late Miocene Pisco Formation (Peru) was reported as having been produced by two differentsized individuals of Cosmopolitodus hastalis (Takakuwa, 2014). Several clues support the conclusion of scavenging (e.g., Cigala-Fulgosi, 1990; Govender and Chinsamy, 2013; Govender, 2015): 1) the combination of both superficial and deep marks (Figure 3.3-4 vs. 3.1-2), which are probably the 
result of the whale and sharks being moved by currents and wave activity; 2) the presence of lateralmedial bite marks on the bones; 3 ) the presence of very deep unserrated marks, suggesting the shark was biting repeatedly over the same area. Overall, the marks in the whale bones of MNUP-1795 are more likely an event of scavenging by sharks on the whale from Panama rather than an event of active predation.

The fossil record of marine mammals in the Burica Formation of Panama has been improving over the past 10 years. Recent discoveries include a cetacean thoracic vertebra (Tobabe Fm.) (Uhen et al., 2010), a partial cetacean rib (Miocene Gatun Fm.) (Uhen et al., 2010), a sirenian caudal vertebra and rib fragments (Miocene Culebra Fm.) (Uhen et al., 2010), dental remains of a sperm whale (Vigil and Laurito, 2014), skull and post-cranial elements from a new inioid odontocete, Isthminia panamensis (Mio-Pliocene Chagres Fm.) (Pyenson et al., 2015), a new kogiid odontocete, Nanokogia isthmia from the Caribbean side of the isthmus (Mio-Pliocene Chagres Fm.) (Vélez-Juarbe et al., 2015), and a dugongine Culebratherium alemani (Miocene Culebra Fm.) (Vélez-Juarbe and Wood, 2019). This new study of a Pliocene cetacean adds to the understanding of marine mammals of the tropical Americas.

The generic diversity of cetaceans, and especially mysticetes, declined around the PliocenePleistocene boundary (Marx et al., 2016), an example of a global turnover event in the marine megafauna (Valenzuela-Toro et al., 2013). This turnover may have been driven by a global reduction of neritic areas (Pimiento et al., 2017), although additional marine megafaunal turnovers may have occurred well into the Pleistocene (e.g.,
Boessenecker, 2013; Tsai et al., 2017). Fossil marine mammals, like the one preserved here, will be useful for understanding the dynamics of the marine fauna in one of the most critical periods of Earth history, the Plio-Pleistocene transition.

\section{ACKNOWLEDGMENTS}

We thank F. Orocú, his son J. Orocú, and P. Pimentel for finding the described specimens and helping with the fieldwork logistics together with the elementary students from Colegio Punta Burica and Escuela Primaria Caña Blanca in Chiriquí Province; L.G. Joly from Universidad Autónoma de Chiriquí, who initiated the first communications, for the recognition of the material; $D$. Cárdenas, L. Mora, S. Gómez, D. Jimenez, and L. Hincapié (CTPA, STRI) for their efforts during fieldwork and geological prospecting; S. Heckadon from the Smithsonian Tropical Research Institute, for help with finding accommodations in Limones; O. Rodríguez, M. Carvalho, A. Rodríguez, and the CTPA lab people whose discussions about geosciences helped give focus to this study; R. Pérez from the Museo de Vertebrados (Universidad de Panamá), E.A. Muñoz from the Museo de Biología Marina y Limnología (Universidad de Panamá), and $\mathrm{K}$. Cárdenas (CTPA, STRI), for their help with the repository logistics at these collections. This research was supported by the Smithsonian Tropical Research Institute, the Anders Foundation, the 1923 Fund, and Gregory D. and Jennifer Walston Johnson; DC is funded by the NSERC CREATE 466283-2015. Three anonymous reviewers and PE editors provided constructive reviews that highly improved the manuscript.

\section{REFERENCES}

Aguilar, A. 2009. Fin whale: Balaenoptera physalus, p. 433-437. In Perrin, W.F., Würsig, B., and Thewissen, J.G.M. (eds.), Encyclopedia of Marine Mammals (Second Edition). Academic Press, London. https://doi.org/10.1016/B978-0-12-373553-9.00102-4

Aguilera, O.A., García, L., and Cozzuol, M.A. 2008. Giant-toothed white sharks and cetacean trophic interaction from the Pliocene Caribbean Paraguaná Formation. Paläontologische Zeitschrift, 82:204-208. https://doi.org/10.1007/bf02988410

Aguirre-Fernández, G., Carrillo-Briceño, J.D., Sánchez, R., Amson, E., and Sánchez-Villagra, M.R. 2017. Fossil Cetaceans (Mammalia, Cetacea) from the Neogene of Colombia and Venezuela. Journal of Mammalian Evolution, 24:71-90. https://doi.org/10.1007/s10914-0169353-x 
Anderson, G.S. and Bell, L.S. 2014. Deep coastal marine taphonomy: Investigation into carcass decomposition in the Saanich Inlet, British Columbia using a baited camera. PLOS ONE, 9:e110710. https://doi.org/10.1371/journal.pone.0110710

Barnes, L.G. and Mitchell, E. 1975. Late Cenozoic northeast Pacific Phocidae. Rapports et Proces-verbaux des Réunions, Conseil International pour l'Exploration de la Mer, 169:34-42.

Baumgartner, P.O., Obando, J.A., Mora, C.R., Channell, J.E.T., and Steck, A. 1989. Paleogene accretion and suspect terranes in southern Costa Rica (Osa, Burica, Central America), p. 529. In Larue, D.K. and Draper, G. (eds.), Transactions of the 12th Caribbean Geological Conference, St Croix, Virgin Islands.

Bianucci, G., Bisconti, M., Landini, W., Storai, T., Zuffa, M., Giuliani, S., and Mojetta, A. 2000. Trophic interaction between white shark, Carcharodon carcharias, and cetaceans: A comparison between Pliocene and recent data from central Mediterranean Sea, p. 33-48. In Vacchi, M., La Mesa, G., Serena, F., and Séret, B. (eds.), Proceedings of the 4th Elasmobranch Association Meeting, Livorno, Italy. Publisher unknown.

Bianucci, G., Collareta, A., Bosio, G., Landini, W., Gariboldi, K., Gioncada, A., Lambert, O., Malinverno, E., de Muizon, C., Varas-Malca, R., Villa, I.M., Coletti, G., Urbina, M., and Di Celma, C. 2018. Taphonomy and palaeoecology of the lower Miocene marine vertebrate assemblage of Ullujaya (Chilcatay Formation, East Pisco Basin, southern Peru). Palaeogeography, Palaeoclimatology, Palaeoecology, 511:256-279. https://doi.org/10.1016/ j.palaeo.2018.08.013

Bianucci, G., Di Celma, C., Collareta, A., Landini, W., Post, K., Tinelli, C., de Muizon, C., Bosio, G., Gariboldi, K., Gioncada, A., Malinverno, E., Cantalamessa, G., Altamirano-Sierra, A., Salas-Gismondi, R., Urbina, M., and Lambert, O. 2016a. Fossil marine vertebrates of Cerro Los Quesos: Distribution of cetaceans, seals, crocodiles, seabirds, sharks, and bony fish in a late Miocene locality of the Pisco Basin, Peru. Journal of Maps, 12:1037-1046. https:// doi.org/10.1080/17445647.2015.1115785

Bianucci, G., Di Celma, C., Landini, W., and Buckeridge, J. 2006. Palaeoecology and taphonomy of an extraordinary whale barnacle accumulation from the Plio-Pleistocene of Ecuador. Palaeogeography, Palaeoclimatology, Palaeoecology, 242:326-342. https://doi.org/10.1016/ j.palaeo.2006.07.004

Bianucci, G., Di Celma, C., Landini, W., Post, K., Tinelli, C., de Muizon, C., Gariboldi, K., Malinverno, E., Cantalamessa, G., Gioncada, A., Collareta, A., Salas-Gismondi, R., VarasMalca, R., Urbina, M., and Lambert, O. 2016b. Distribution of fossil marine vertebrates in Cerro Colorado, the type locality of the giant raptorial sperm whale Livyatan melvillei (Miocene, Pisco Formation, Peru). Journal of Maps, 12:543-557. https://doi.org/10.1080/ 17445647.2015.1048315

Bianucci, G., Sorce, B., Storai, T., and Landini, W. 2010. Killing in the Pliocene: Shark attack on a dolphin from Italy. Palaeontology, 53:457-470. https://doi.org/10.1111/j.14754983.2010.00945.x

Bisconti, M. 2010. New description of 'Megaptera' hubachi Dathe, 1983 based on the holotype skeleton held in the Museum für Naturkunde, Berlin. Quaderni del Museo di Storia Naturale di Lovorno, 23:37-68.

Boessenecker, R.W. 2013. Pleistocene survival of an archaic dwarf baleen whale (Mysticeti: Cetotheriidae). Naturwissenschaften, 100:365-371. https://doi.org/10.1007/s00114-0131037-2

Bolli, H.M. and Bermúdez, P.J. 1965. Zonation based on planktonic foraminifera of middle Miocene to Pliocene warm-water sediments. Asociación Venezolana de Geología, Mineralogía y Petróleo. Boletín Informativo, 8:119-149.

Bornatowski, H., Wedekin, L.L., Heithaus, M.R., Marcondes, M.C.C., and Rossi-Santos, M.R. 2012. Shark scavenging and predation on cetaceans at Abrolhos Bank, eastern Brazil. Journal of the Marine Biological Association of the United Kingdom, 92:1767-1772. https:// doi.org/10.1017/S0025315412001154

Brisson, M.-J. 1762. Regnum Animale in Classes IX. Distributum, Sive, Synopsis Methodica: Sistens Generalem Animalium Distributionem in Classes IX, \& Duarum Primarum Classium, Quadrupedum Scilicet \& cetaceorum, particularem divisionem in Ordines, Sectiones, Genera \& Species: cum Brevi Cujusque Speciei Descriptione, Citationibus Auctorum de iis Tractantium, Nominibus eis ab ipsis \& Nationibus Impositis, Nominibusque Vulgaribus, Apud Theodorum Haak, Lugduni Batavorum. https://doi.org/10.5962/bhl.title.40361 
Carrillo-Briceño, J.D., Aguilera, O.A., De Gracia, C., Aguirre-Fernández, G., Kindlimann, R., and Sánchez-Villagra, M.R. 2016. An early Neogene elasmobranch fauna from the southern Caribbean (western Venezuela). Palaeontologia Electronica, 19.2:1-32. https://doi.org/ 10.26879/664 palaeo-electronica.org/content/2016/1541-early-neogene-elasmobranchii

Carrillo-Briceño, J.D., Carrillo, J.D., Aguilera, O.A., and Sanchez-Villagra, M.R. 2018. Shark and ray diversity in the Tropical America (Neotropics) - An examination of environmental and historical factors affecting diversity. PeerJ, 6:e5313. https://doi.org/10.7717/peerj.5313

Cicimurri, D.J. and Knight, J.L. 2009. Two shark-bitten whale skeletons from coastal plain deposits of South Carolina. Southeastern Naturalist, 8:71-83.

Cigala-Fulgosi, F. 1990. Predation (or possible scavenging) by a great white shark on an extinct species of bottlenosed dolphin in the Italian Pliocene. Tertiary

Research, 12:17-36.

Coates, A.G. 1997. The forging of Central America, p. 1-37. In Coates, A.G. (ed.), Central America: A Natural and Cultural History. Yale University Press, New Haven.

Coates, A.G., Jackson, J.B.C., Collins, L.S., Dowsett, H.J., Bybell, L.M., Cronin, T.M., Jung, P., and Obando, J.A. 1992. Closure of the Isthmus of Panama: The near-shore marine record of Costa Rica and western Panama. GSA Bulletin, 104:814-828. https://doi.org/10.1130/00167606(1992)104\%3C0814:cotiop\%3E2.3.co;2

Coates, A.G. and Obando, J.A. 1996. The geologic evolution of the Central American Isthmus, p. 21-56. In Jackson, J.B.C., Budd, A.F., and Coates, A.G. (eds.), Evolution and Environment in Tropical America. University Chicago Press, Chicago.

Collareta, A., Lambert, O., Landini, W., Di Celma, C., Malinverno, E., Varas-Malca, R., Urbina, M., and Bianucci, G. 2017. Did the giant extinct shark Carcharocles megalodon target small prey? Bite marks on marine mammal remains from the late Miocene of Peru.

Palaeogeography, Palaeoclimatology, Palaeoecology, 469:84-91. https://doi.org/10.1016/ j.palaeo.2017.01.001

Collins, L.S., Coates, A.G., Jackson, J.B.C., and Obando, J.A. 1995. Timing and rates of emergence of the Limón and Bocas del Toro basins: Caribbean effects of Cocos Ridge subduction? p. 263-289. In Mann, P. (ed.), Geologic and Tectonic Development of the Caribbean Plate Boundary in Southern Central America. Geological Society of America Special, Boulder, Colorado.

Corrigan, J., Mann, P., and Ingle, J.C., Jr. 1990. Forearc response to subduction of the Cocos Ridge, Panama-Costa Rica. GSA Bulletin, 102:628-652. https://doi.org/10.1130/00167606(1990)102\%3C0628:frtsot\%3E2.3.co;2

Curtis, T.H., Kelly, J.T., Menard, K.L., Laroche, R.K., Jones, R.E., and Klimley, A.P. 2006. Observations on the behavior of white sharks scavenging from a whale carcass at Point Reyes, California. California Fish and Game, 92:113-124.

Dathe, F. 1983. Megaptera hubachi n. sp., ein fossiler Bartenwal aus marinen Sandsteinschichten des tieferen Pliozans Chiles. Zeitschrift fur Geologische Wissenschaften, 11:813-848.

Davidson, D. 2010. Recent Uplift of the Burica Peninsula, Panama and Costa Rica, Recorded by Marine Terraces. Unpublished PhD Thesis, Trinity University, San Antonio, Texas, USA.

De Gracia, C. 2015. Paleoceanografía del Pacífico este tropical y la restricción del afloramiento en las costas de Panamá, p. 47-63. In Rodriguez, F.O.D. (ed.), Historia Natural del Istmo de Panamá. Toppan Leng Fung, Hong Kong.

De Gracia, C., O’Dea, A., Rodríguez, F., and D'Croz, L. 2012. Respuesta ambiental en el Pacífico frente a la subducción de la dorsal asísmica de Cocos (Panamá y Costa Rica). Revista de Biología Tropical, 60:893-908.

Deméré, T.A. 1986. The fossil whale, Balaenoptera davidsonii (Cope, 1872), with a review of other Neogene species of Balaenoptera (Cetacea: Mysticeti). Marine Mammal Science, 2:277-298. https://doi.org/10.1111/j.1748-7692.1986.tb00136.x

Deméré, T.A., Berta, A., and McGowen, M.R. 2005. The taxonomic and evolutionary history of fossil and modern Balaenopteroid Mysticetes. Journal of Mammalian Evolution, 12:99-143. https://doi.org/10.1007/s10914-005-6944-3

Deméré, T.A. and Cerutti, R.A. 1982. A Pliocene shark attack on a cethotheriid whale. Journal of Paleontology, 56:1480-1482.

de Muizon, C. and DeVries, T.J. 1985. Geology and paleontology of late Cenozoic marine deposits in the Sacaco area (Peru). Geologische Rundschau, 74:547-563. 
DeVries, T.J. 1988. The geology of late Cenozoic marine terraces (tablazos) in northwestern Peru. Journal of South American Earth Sciences, 1:121-136. https://doi.org/10.1016/08959811(88)90030-2

Di Celma, C., Malinverno, E., Bosio, G., Collareta, A., Gariboldi, K., Gioncada, A., Molli, G., Basso, D., Malca, V., and Rafael, M. 2017. Sequence stratigraphy and paleontology of the Upper Miocene Pisco Formation along the western side of the lower Ica Valley (Ica Desert, Peru). Rivista Italiana di Paleontologia e Stratigrafia (Research in Paleontology and Stratigraphy), 123:255-274.

Dicken, M.L., Kock, A.A., and Hardenberg, M. 2015. First observations of dusky sharks (Carcharhinus obscurus) attacking a humpback whale (Megaptera novaeangliae) calf. Marine and Freshwater Research, 66:1211-1215. https://doi.org/10.1071/MF14317

Ehret, D.J., Macfadden, B.J., Jones, D.S., Devries, T.J., Foster, D.A., and Salas-Gismondi, R. 2012. Origin of the white shark Carcharodon (Lamniformes: Lamnidae) based on recalibration of the Upper Neogene Pisco Formation of Peru. Palaeontology, 55:1139-1153. https://doi.org/10.1111/j.1475-4983.2012.01201.x

Ehret, D.J., MacFadden, B.J., and Salas-Gismondi, R. 2009. Caught in the act: Trophic interactions between a 4-million-year-old white shark (Carcharodon) and mysticete whale from Peru. Palaios, 24:329-333. https://doi.org/10.2110/palo.2008.p08-077r

Fallows, C., Gallagher, A.J., and Hammerschlag, N. 2013. White sharks (Carcharodon carcharias) scavenging on whales and its potential role in further shaping the ecology of an apex predator. PLOS ONE, 8:e60797. https://doi.org/10.1371/journal.pone.0060797

Flower, W.H. 1864. Notes on the skeletons of whales in the principal museums of Holland and Belgium, with descriptions of two species apparently new to science. Proceedings of the Zoological Society of London, 1864:384-420.

Fordyce, R.E. and Marx, F.G. 2018. Gigantism precedes filter feeding in baleen whale evolution. Current Biology, 28:1670-1676.e1672. https://doi.org/10.1016/j.cub.2018.04.027

Gartner, S., Jr. 1969. Correlation of Neogene planktonic foraminifer and calcareous nannofossil zones. Gulf Coast Association of Geological Societies Transactions, 19:585-599.

Godfrey, S., Ellwood, M., Groff, S., and Verdin, M. 2018. Carcharocles-bitten odontocete caudal vertebrae from the coastal eastern United States. Acta Palaeontologica Polonica, 63:463468. https://doi.org/10.4202/app.00495.2018

Govender, R. 2015. Shark-cetacean trophic interaction, Duinefontein, Koeberg, (5 Ma), South Africa. South African Journal of Science, 111:1-7. https://doi.org/10.17159/sajs.2015/ 20140453

Govender, R. and Chinsamy, A. 2013. Early Pliocene (5 Ma) shark-cetacean trophic interaction from Langebaanweg, western coast of South Africa. Palaios, 28:270-277. https://doi.org/ 10.2110/palo.2012.p12-058r

Gray, J.E. 1864. XXXVIII.-Notes on the Whalebone-Whales; with a synopsis of the species. Annals and Magazine of Natural History, 14:345-353. https://doi.org/10.1080/ 00222936408681724

Harington, C.R. 1977. Marine mammals in the Champlain Sea and the Great Lakes. Annals of the New York Academy of Sciences, 288:508-537.

Hilgen, F.J., Lourens, L.J., Van Dam, J.A., Beu, A.G., Boyes, A.F., Cooper, R.A., Krijgsman, W., Ogg, J.G., Piller, W.E., and Wilson, D.S. 2012. The Neogene Period, p. 923-978. In Gradstein, F.M., Ogg, J.G., Schmitz, M.D., and Ogg, G.M., (eds.), The Geologic Time Scale. Elsevier, Boston.

Lambert, O., Bianucci, G., Post, K., de Muizon, C., Salas-Gismondi, R., Urbina, M., and Reumer, J. 2010. The giant bite of a new raptorial sperm whale from the Miocene epoch of Peru. Nature, 466:105. https://doi.org/10.1038/nature09067

Leon-Rodriguez, L. 2007. Benthic foraminiferal record of the Pleistocene uplift of the sedimentary deposits of the Burica Peninsula (Costa Rica-Panama) as a result of Cocos Ridge subduction beneath the Central American Arc. Unpublished PhD Thesis, Florida International University, Florida, USA.

Long, D.J. and Jones, R.E. 1996. White shark predation and scavenging on cetaceans in the Eastern North Pacific Ocean, p. 293-307. In Kimley, A.P. and Ainley, D.G. (eds.), Great White Sharks: The Biology of Carcharodon carcharias. Academic Press, San Diego. https://doi.org/ 10.1016/B978-012415031-7/50028-8 
Lucas, S.G., McLeod, S.A., Barnes, L.G., Alvarado, G.E., García, R., and Espinoza, E. 2009. A baleen whale from the Pliocene of Nicaragua. Revista Geológica de América Central, 41:1724.

Martínez, J.N. and Jacay, J. 2000. Evolución sedimentológica y paleontológica del paleodelta del Chira (Departamento de Piura) durante el Pleistoceno, datos preliminares. In X Congreso Peruano de Geología, Lima. Editor and publisher unknown.

Marx, F.G. and Fordyce, R.E. 2015. Baleen boom and bust: A synthesis of mysticete phylogeny, diversity and disparity. Royal Society Open Science, 2:140434. https://doi.org/10.1098/ rsos.140434

Marx, F.G. and Kohno, N. 2016. A new Miocene baleen whale from the Peruvian desert. Royal Society Open Science, 3:160542. https://doi.org/10.1098/rsos.160542

Marx, F.G., Lambert, O., and Uhen, M.D. 2016. Cetacean Paleobiology. John Wiley \& Sons, Chichester, UK.

Miller, W.E. 1971. Pleistocene Vertebrates of the Los Angeles Basin and Vicinity: (Exclusive of Rancho La Brea). Los Angeles County Museum of Natural History, Los Angeles.

Mora, C., Baumgartner, P.O., and Hottinger, L. 1989. Eocene shallow water carbonate facies with larger foraminifera in the Cano Accretionary Complex, Cano Island and Osa Peninsula (Costa Rica, Central America), p. 122. In Larue, D.K. and Draper, G. (eds.), Transactions of the 12th Caribbean Geological Conference, St Croix, Virgin Islands.

Morgan, G. S. 1994. Miocene and Pliocene marine mammal faunas from the Bone Valley Formation of Central Florida, p. 239-268. In Berta, A. and Deméré, T.D. (eds.), Contributions in Marine Mammal Paleontology Honoring Frank C. Whitmore, Jr. San Diego Society of Natural History, San Diego.

Noakes, S.E., Pyenson, N.D., and McFall, G. 2013. Late Pleistocene gray whales (Eschrichtius robustus) offshore Georgia, U.S.A., and the antiquity of gray whale migration in the North Atlantic Ocean. Palaeogeography, Palaeoclimatology, Palaeoecology, 392:502-509. https:// doi.org/10.1016/j.palaeo.2013.10.005

Noriega, J.I., Cione, A.L., and Aceñolaza, F.G. 2007. Shark tooth marks on Miocene balaenopterid cetacean bones from Argentina. J Neues Jahrbuch für Geologie und Paläontologie-Abhandlungen, 245:185-192. https://doi.org/10.1127/0077-7749/2007/02450185

O'Dea, A., Hoyos, N., Rodríguez, F., Degracia, B., and De Gracia, C. 2012. History of upwelling in the Tropical Eastern Pacific and the paleogeography of the Isthmus of Panama. Palaeogeography, Palaeoclimatology, Palaeoecology, 348-349:59-66. https://doi.org/ 10.1016/j.palaeo.2012.06.007

O'Dea, A., Rodríguez, F., De Gracia, C., and Coates, A.G. 2007. La Paleontología marina en el Istmo de Panamá. Canto Rodado, 2:149-179.

Olsson, A.A. 1942. Tertiary and Quaternary fossils from the Burica Peninsula of Costa Rica and Panama. Bulletin of American Palaeontology, 26:106.

Pimiento, C., Griffin, J.N., Clements, C.F., Silvestro, D., Varela, S., Uhen, M.D., and Jaramillo, C. 2017. The Pliocene marine megafauna extinction and its impact on functional diversity. Nature Ecology \& Evolution, 1:1100-1106. https://doi.org/10.1038/s41559-017-0223-6

Pyenson, N.D. and Sponberg, S.N. 2011. Reconstructing body size in extinct crown Cetacea (Neoceti) using allometry, phylogenetic methods and tests from the fossil record. Journal of Mammalian Evolution, 18:269. https://doi.org/10.1007/s10914-011-9170-1

Pyenson, N.D., Vélez-Juarbe, J., Gutstein, C.S., Little, H., Vigil, D., and O’Dea, A. 2015. Isthminia panamensis, a new fossil inioid (Mammalia, Cetacea) from the Chagres Formation of Panama and the evolution of 'river dolphins' in the Americas. PeerJ, 3:e1227. https:// doi.org/10.7717/peerj.1227

Schouten, S. 2017. De witte haai (Carcharodon carcharias Linnaeus, 1758) in het (Vroeg) Holoceen van de Noordzee? Cranium, 34:68-73.

Schwarzhans, W. and Aguilera, O.A. 2013. Otoliths of the Myctophidae from the Neogene of tropical America. Palaeo Ichthyologica, 13:83-150.

Slater, G.J., Goldbogen, J.A., and Pyenson, N.D. 2017. Independent evolution of baleen whale gigantism linked to Plio-Pleistocene ocean dynamics. Proceedings of the Royal Society B: Biological Sciences, 284:20170546. https://doi.org/10.1098/rspb.2017.0546 
Takakuwa, Y. 2014. A dense occurrence of teeth of fossil "mako" shark ("Isurus":

Chondrichthyes, Lamniformes), associated with a balaenopterid-whale skeleton of the Late Miocene Pisco Formation, Peru, South America. Bulletin of Gunma Museum of Natural History, 18:77-86. (In Japanese with English abstract)

Tsai, C.-H. and Boessenecker, R.W. 2017. The earliest-known fin whale, Balaenoptera physalus, from the Early Pleistocene of northern California, USA. Journal of Vertebrate Paleontology, 37:e1306536. https://doi.org/10.1080/02724634.2017.1306536

Tsai, C.-H., Collareta, A., Fitzgerald, E.M.G., Marx, F.G., Kohno, N., Bosselaers, M., Insacco, G., Reitano, A., Catanzariti, R., Oishi, M., and Bianucci, G. 2017. Northern pygmy right whales highlight Quaternary marine mammal interchange. Current Biology, 27:1058-1059. https:// doi.org/10.1016/j.cub.2017.08.056

Tsai, C.-H. and Kohno, N. 2016. Multiple origins of gigantism in stem baleen whales. The Science of Nature, 103:89. https://doi.org/10.1007/s00114-016-1417-5

Uhen, M.D., Coates, A.G., Jaramillo, C.A., Montes, C., Pimiento, C., Rincon, A., Strong, N., and Vélez-Juarbe, J. 2010. Marine mammals from the Miocene of Panama. Journal of South American Earth Sciences, 30:167-175. https://doi.org/10.1016/j.jsames.2010.08.002

Valenzuela-Toro, A.M., Gutstein, C.S., Varas-Malca, R.M., Suarez, M.E., and Pyenson, N.D. 2013. Pinniped turnover in the South Pacific Ocean: New evidence from the Plio-Pleistocene of the Atacama Desert, Chile. Journal of Vertebrate Paleontology, 33:216-223. https://doi.org/ 10.1080/02724634.2012.710282

van Beneden, P.J. 1882. Description des ossements fossiles des environs d'Anvers, Troisième partie, Cétacés, genres: Megaptera, Balaenoptera, Burtinopsis, et Erpetocetus. Annales du Musée Royal d'Histoire Naturelle de Belgique, Bruxelles, Sér. Paléontologique, 7:1-87.

Vélez-Juarbe, J. and Wood, A.R. 2018. An early Miocene dugongine (Sirenia: Dugongidae) from Panama, Journal of Vertebrate Paleontology, 38:e1511799. https://doi.org/10.1080/ 02724634.2018.1511799

Vélez-Juarbe, J., Wood, A.R., De Gracia, C., and Hendy, A.J.W. 2015. Evolutionary patterns among living and fossil kogiid sperm whales: Evidence from the Neogene of Central America. PLOS ONE, 10:e0123909. https://doi.org/10.1371/journal.pone.0123909

Vigil, D.I. and Laurito, C.A. 2014. Nuevos restos de un Odontoceti fósil (Mammalia: Cetacea, Physeteroidea) para el Mioceno tardío de Panamá, América Central. Revista Geológica de América Central, 50:213-217. 